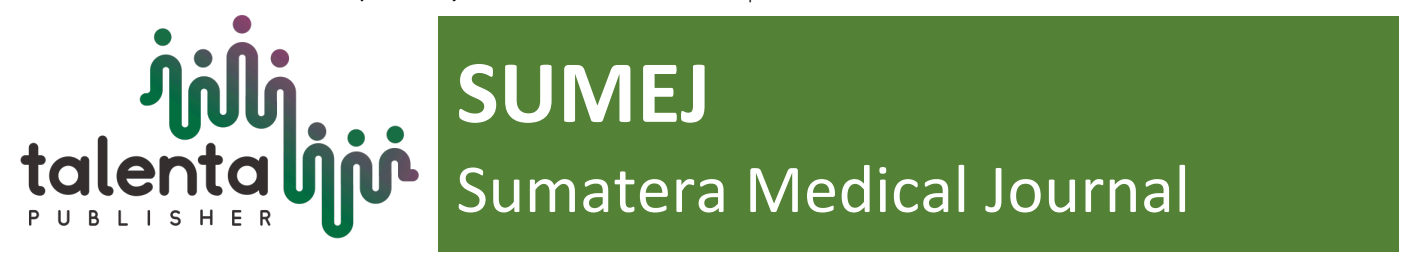

\title{
Identification of Candida Species on The Skin of Diabetes Mellitus Patients
}

\author{
OK. Muhammad Al Hafiz ${ }^{1}$, Rina Amelia ${ }^{2}$, Nelva Karmila Jusuf ${ }^{3}$ \\ ${ }^{I}$ Participant of Educational Doctor Profession Program, Faculty of Medicine, Universitas Sumatera Utara \\ ${ }^{2}$ Department of Medicine Community, Faculty of Medicine, Universitas Sumatera Utara \\ ${ }^{3}$ Department of Dermatovenerology, Faculty of Medicine, Universitas Sumatera Utara
}

\begin{abstract}
Background: Intertriginous candidiasis is a type of candidiasis which the lesion lies in the folds of the armpit, groin, intergluteal, folding of the breast, between the fingers or the toes, glans penis, and the umbilicus. One of the risk factors for intertriginous candidiasis is diabetes mellitus (DM). DM is a typical clinical syndrome characterized by the presence of hyperglycemia which is caused by deficiency or the decrease of insulin effectivity. Fungal infection of the skin with Candida species becomes easier in patients with immunocompromised conditions such as DM patients. Objective: To identify the Candida species in DM patient's skin. Method: This research is an observational descriptive study with cross sectional design. This research identifies Candida species from $30 \mathrm{DM}$ patients at The Public Health Center Sentosa Baru Medan who met the inclusion and exclusion criteria by skin scraping with $\mathrm{KOH} 10 \%$ and slide culture. Results: The location of the rash was found in the crotch folds $63.3 \%$ and in the intergluteal $36.7 \%$. All samples (100\%) showed positive fungus structure with $\mathrm{KOH} 10 \%$ examination. On the examination of slide culture with Saboraoud Dextrose Agar media and identification of slide colony with Corn Meal Agar medium as many as $60 \%$ Candida spesies was found with overall species are Candida albicans.
\end{abstract}

Keyword: Candida Species, Intertriginosa Candidiasis, Diabetes Mellitus (DM)

Received 30 May 2018 | Revised 10 July 2018 | Accepted 20 September 2018

\footnotetext{
*Corresponding author at: Faculty of Medicine, Jalan Doktor Mansyur No.5 Kampus USU Padang Bulan, Medan,
} Sumatera Utara 20155 


\section{Introduction}

Candida is a fungal consisting of many species, but only 17 species are reported to infect humans. These species include Candida albicans, Candida glabrata, Candida parapsilosis, Candida tropicalis, Candida krusei, Candida kefyr, Candida guilliermondii, Candida lusitaniae, Candida dubliniensis [1-4].

Candidiasis can be found all over the world, relatively common in the tropical area that can affect all ages, both male and female [5,6]. Research conducted at National Skin Center, Singapore, from 1999-2003 placed candidiasis (11.1\%) in the third most cases of mycosis after dermatophytosis $(57 \%)$ and pityriasis versicolor $(25.2 \%)$. From all of the studies were found, most of the cases are intertriginous candidiasis (69.8\%). This is due to the hot and humid climate of Singapore [7]. Similar results were found in studies conducted in Bangladesh, where candidiasis ranks the third positions of superficial fungal infections [8].

Candida infection occurs when there are factors that can nourish the growth or facilitate the invasion of the tissues due to the weak resistance of the host. The factors that cause candidiasis are divided into two, endogenous and exogenous predisposing factors. Endogenous predisposing factors such as pregnancy (due to $\mathrm{pH}$ changes in the vagina), obesity (due to sweat), iatrogenic, endocrinopaty (DM), chronic disease (tuberculosis, lupus erythematosus with poor general circumstances), age (erderly and younger infants exposed to the infection due to imperfect immunological status), immunologic (genetic disease). Exogenous predisposing factors such as: climate, skin hygiene, foot bath habit and contact with patients [5].

One form of candidiasis cutis is intertriginous candidiasis. Intertriginous candidiasis lies in the area of the underarm skin fold, groin, intergluteal, folding of the breast, between the fingers or toes, glans penis, and umbilicus, sirkumskripta, scaly, wet, and erythematous. The lesion is surrounded by satellites such as tiny vesicles and pustules or bullae which, when it breaks out it leaves erosive areas, with rough edges and develops as primary lesions [5].

As known that DM is a predisposing factor of intertriginous candidiasis caused by the changes in the body's defense system [9-14].

DM is a hyperglycemia disease characterized by absolute absence of insulin or a relative decrease in cell insensitivity to insulin [15]. The metabolic status of DM patients provides the advantage by fulfilling specific nutritional requirements and facilitating the growth of fungi, especially Candida species [16]. In a study at the General Hospital of Dr. Soetomo Surabaya, DM as a risk factor for the occurrence of intertriginosa candidiasis. Where the average patients with history of DM had a 3.26 times greater risk than no history of DM. The purpose of this study was to identify Candida species on the skin of DM patients. 


\section{Methodology}

This research is an observational research. The studies used in this research is cross sectional. This study was conducted from March to December 2016 at the Sentosa Baru Public Health Center Medan because it has many DM patients so that fullfill the inclusion criteria where it has a description of skin disorders in the armpit, groin, intergluteal, fingers or toes, glans penis and umbilicus and still a DM patient at Sentosa Baru Health Center Medan. Data that have been collected at the time of filling patient status data then examined skin scrapping with $\mathrm{KOH} 10 \%$ inspection and fungal culture in the laboratory of Microbiology FK USU.

Table 1. The Distribution of DM Patients By Sex

\begin{tabular}{lcc}
\hline Sex & $\mathbf{N}$ & $\mathbf{\%}$ \\
\hline Male & 12 & 40 \\
Female & 18 & 60 \\
\hline Total & & \\
\hline
\end{tabular}

Table 1 from the table above it is found that the most patient were female with a total of $60 \%$ and the rast were men with a total of $40 \%$. Based on the 2007 National Basic Health Research report in Indonesia (RISKENDAS 2007) DM is more common found in woman with a percentage of $64.9 \%$ and men with a percentage of 35.1\% [17]. Maulina et al in H.Adam Malik General Hospital Medan found that most of the patient were with percentage of female $61.9 \%$ while with percentage of gender of men $38.1 \%$ [18].

Table 2. The Distribution of DM Patients By Age

\begin{tabular}{lcc}
\hline Age & n & \% \\
\hline $46-55$ (initial elderly) & 5 & 16,7 \\
$56-65$ (late age) & 17 & 56,7 \\
$>65$ (elderly) & 8 & 26,7 \\
\hline Total & $\mathbf{3 0}$ & $\mathbf{1 0 0}$ \\
\hline
\end{tabular}

Table 2 The table above found most people was found to suffer more from skin disease in the 5665 year age group of $56.7 \%$. In the study, Maulina et al found that intertriginous candidiasis was most common in the age group 45-65 years $(45.95 \%)$ and followed by age group 65 years (21.62\%). The age group above 50 years ranks first with $40 \%$ and the age group 30 to 50 years with $15.5 \%$ [17]. This is because immune system status in the elderly has decieased. In addition, 
elderly people are susceptible to some diseases such as diabetes mellitus, which is one of the risk factor of intertriginous candidiasis [19].

Table 3. The Distribution of DM Patients By The Level Of Education

\begin{tabular}{lcr}
\hline Education Level & n & \% \\
\hline Primary School & 4 & 13,3 \\
Junior High School & 11 & 36,7 \\
Senior High & 12 & 40 \\
School & 3 & 10 \\
Bachelor & & \\
\hline Total & $\mathbf{3 0}$ & $\mathbf{1 0 0}$ \\
\hline
\end{tabular}

Table 3 The table above found that the incidence of candidiasis $40 \%$ in high school students and followed by $36.7 \%$ of junior high school students. Knowledge of a person is very closely related to the achieved education. People who have low level of education, knowledge about health is certainly not too profound. This could be the reason of them not knowing DM disease in depth. Other behaviors are based on knowledge and positive attitude [20]. The patient's knowledge of Diabetes Mellitus is a tool that helps the patient manage Diabetes during their lifetime. The more and better the patients understand their illness, the more they understand how to change their behavior and lifestyle, and why it is needed [21].

Table 4. The Distribution of DM Patients Based on The Duration in Suffering in Diabetes Mellitus

\begin{tabular}{ccr}
\hline The duration & n & \% \\
\hline <1 year & 3 & 10 \\
$1-5$ year & 7 & 23,3 \\
6 - 10 year & 7 & 23,3 \\
$11-20$ year & 9 & 40 \\
$>20$ year & 4 & 13,3 \\
\hline Total & $\mathbf{3 0}$ & $\mathbf{1 0 0}$
\end{tabular}

Table 4 from the table above it was found that the duration of suffering DM for 11-20 years was found in 9 people (30\%). The long duration of DM affects patients' behavior toward treatment, 
patients who are still newly diagnosed with DM generally will be open and happy to be given counseling about drugs, because they are still not familiar with the disease and treatment experienced, so there is a great sense of curiosity towards the disease and its treatment. While patients who have long suffered with DM, they will assume that the disease is not dangerous, or in their experience the results are not so satisfactory during their treatment, they will resigned and less concerned about the disease so they become less interested when given information about their diseases and medicines [22].

Table 5. The Distribution of DM Patients Based on The Location of The Rash

\begin{tabular}{ccc}
\hline $\begin{array}{c}\text { The Location of } \\
\text { the Rash }\end{array}$ & $\mathbf{n}$ & $\mathbf{\%}$ \\
\hline Groins & 19 & 63,3 \\
Intergluteal & 11 & 36,7 \\
\hline Total & $\mathbf{3 0}$ & $\mathbf{1 0 0}$ \\
\hline
\end{tabular}

Table 5 from the table above it was found that the rash in the skin fold areas affected by intertriginous candidiasis gave a result of 19 people $(63.3 \%)$ in the groin area. This is because the groins are the most closed part when someone is dressed. When the temperature of the environment is hot and a person is sweating, the groins become the most moist part because of the sweat. This condition supports the growth of candida fungal in the groin and eventually leads to intertriginous candidiasis [19].

Table 6. 10\% Koh Examination

\begin{tabular}{lcc}
\hline \multicolumn{1}{c}{ KOH 10\% } & $\mathbf{n}$ & $\mathbf{\%}$ \\
\hline Hyphae (+) Spore(+) & 2 & 6,7 \\
Hyphae (+) Spore (-) & 0 & 0 \\
Hyphae(-) Spore (+) & 28 & 93,3 \\
Hyphae(-) Spore (-) & 0 & 0 \\
\hline Total & $\mathbf{3 0}$ & $\mathbf{1 0 0}$ \\
\hline
\end{tabular}

Table 6 From the table above, it was found $10 \% \mathrm{KOH}$ examination results in its function to dissolve debris and lipids from skin, hair, and mucous scrapings. 30 samples was tested with $\mathrm{KOH}$ $10 \%$ examination, where hyphae (-) and spore $(+)$ was found in 28 samples $(93.3 \%)$ and the hyphae $(+)$ spotted (artroconidia) spore (-) in 2 samples $(6.7 \%)$. Next, the fungal culture will be 
examined. Morphologically has several forms of yeast elements such as yeast cells (blastopora/yeast), hyphae and intermedia/pseudohifa form. The yeast cells are round, oval or round oval with size $2-5 \mu \times 5-28 \mu$. Candida multiplies itself by forming bud that will continue to elongate to form a pseudohyphae [23].

Table 7. Overview of Fungal Culture

\begin{tabular}{ccc}
\hline Yeast species & $\mathbf{n}$ & $\mathbf{\%}$ \\
\hline Candida albicans & 18 & 60 \\
No Candida was found & 12 & 40 \\
\hline Total & $\mathbf{3 0}$ & $\mathbf{1 0 0}$ \\
\hline
\end{tabular}

Table 7 From the table above, it showes that 18 samples of Candida albicans $(60 \%)$ and no Candida was found in 12 samples (40\%). This is in line with Maulina's and her friends' findings. Where they found that Candida albicans as much as $67 \%$ [18].

Identification of species can be done macroscopically and microscopically. Macroscopically it can be done on chromogenic media (CHROMagar). In this medium Candida species will form different colony colors. Candida albicans form a green colony[24].

Identification of microscopic morphologic species can be done by fungal culture on certain mediums, such as Corn Meal Agar. In this medium Candida albicans forms a terminal klamidospora which is a large yeast cell with thick walls and is located at the end of the hyphae [23].

One of the risk factors in intertriginous candidiasis is DM. The condition of chronic hyperglycemia in diabetic patients is associated with long-term complications that one of them attacks the skin.26 The skin becomes one of the organs often affected by DM. Skin manifestations of infection become one of the most common chronic complications seen in DM patients [25].

In addition, there are several other predisposing factors found in the respondents when they were filling the status of DM participants where there are areas of moist skin folds and lack of maintaining the cleanliness of the skin area. From the daily bathing habits, the use of soap which is only occasionally, the frequency of changing clothes in a day it was found only 1 time or 2 times in a day, where the lack of behavior to keep the skin area clean and sweaty habits that found moisture in the skin folds. This condition supports the growth of Candida fungus in the skin folds and eventually leads to intertriginous candidiasis. 


\section{Conclusion}

The identification of Candida species in DM patient skin found that there were Candida albicans species as much as $60 \%$.

\section{Suggestion}

This study can be continued by identification of other fungi such as dermatophytes in DM patients. In the need for counseling and plenary services for DM patients and skin disorders associated with it.

\section{REFERENCES}

[1] S. Verma, M.P. Heffernan, Superficial Fungal Infections, Wolff K, Goldsmith La, Et Al. Fitzpatrick's Dermatology In General Medicine. (2008) 1807-16.

[2] S.H. Aliyu, D.A. Enoch, I.I. Abubakar, R. Ali, A.J. Carmichael, M. Farrington, A.M.L. Lever, Candidaemia in a Large Teaching Hospital: A Clinical Audit, Journal of The Association Of Physicians. 99 (2006) 655-663.

[3] R. Wahyuningsih, H.-J. Freisleben, H.-G. Sonntag, P. Schnitzler, Simple And Rapid Detection Of Candida Albicans Dna In Serum By Pcr For Diagnosis Of Invasive Candidiasis, Journal Of Clinical Microbiology. 38 (2000) 3016-3021.

[4] W.E. Dismukes, P.G. Pappas, J.D. Sobel, Clinical Mycology, Oxford University Press, Usa, 2003.

[5] A. Djuanda, M. Hamzah, S. Aisah, Ilmu Penyakit Kulit Dan Kelamin, Jakarta: Fkui. (2007).

[6] B. Havlickova, V.A. Czaika, M. Friedrich, Epidemiological Trends In Skin Mycoses Worldwide, Mycoses. 51 (2008) 2-15.

[7] T. Hiok-Hee, Superficial Fungal Infections Seen At The National Skin Centre, Singapore, 日本医真菌学会雑誌= Japanese Journal Of Medical Mycology. 46 (2005) 77-80.

[8] M.H. Rahman, M. Hadiuzzaman, M.K.J. Bhuiyan, N. Islam, N.P. Ansari, S.A. Mumu, I.J. Chowdhury, Prevalence Of Superficial Fungal Infections In The Rural Areas Of Bangladesh, Iran J Dermatol. 14 (2011) 86-91.

[9] J.D. Davis, Superficial Fungal Infections Of The Skin: Tinea Corporis, Tinea Pedis, And Candida Intertrigo, Primary Care Update For Ob/Gyns. 2 (1995) 157-161.

[10] I. Goodall, Hba1c Standardisation Destination-Global Ifcc Standardisation How, Why, Where And When: A Tortuous Pathway From Kit Manufacturers, Via Inter-Laboratory Lyophilized And Whole Blood Comparisons To Designated National Comparison Schemes, Clinical Biochemist Reviews. 26 (2005) 5.

[11] S. Ragunatha, B. Anitha, A.C. Inamadar, A. Palit, S.S. Devarmani, Cutaneous Disorders In 500 Diabetic Patients Attending Diabetic Clinic, Indian Journal of Dermatology. 56 (2011) 160.

[12] The Frequency Of Superficial Fungal Infections In Patients With Diabetes Mellitus And Its Relation To The Level Of Hbalc - Original Article, (2001). Http://www.Turkjem.Org/ (Accessed August 6, 2018).

[13] P.E. Indonesia, Pengelolaan Dan Pencegahan Diabetes Melitus Tipe 2 Di Indonesia, Pb. Perkeni. (2015).

[14] R.J. Mahler, M.L. Adler, Type 2 Diabetes Mellitus: Update On Diagnosis, Pathophysiology, And Treatment, The Journal Of Clinical Endocrinology \& Metabolism. 84 (1999) 11651171. 
[15] M.A. Wani, I. Hassan, H.M. Bhat, Q.M. Ahmed, Cutaneous Manifestations Of Diabetes Mellitus: A Hospital Based Study In Kashmir, India, Egyptian Dermatol Online J. 5 (2009) 5.

[16] S. Nasreen, I. Ahmed, M.U. Jahangir, Cutaneous Manifestations Of Diabetic Foot, Journal of Pakistan Association Of Dermatology. 19 (2016) 13-17.

[17] K.K. Ri, Badan Penelitian Dan Pengembangan Kesehatan, Riset Kesehatan Dasar. (2013).

[18] K. Muis, N.K. Jusuf, Hubungan Kadar Hemoglobin Glikosilat (Hba1c) Dengan Kandidiasis Kutis Pada Pasien Diabetes Tipe 2 Di Rsup Haji Adam Malik Medan, Master's Thesis, N.D.

[19] S.R. Wowor, H.E. Pandaleke, M.G. Kapantow, Profil Kandidosis Intertriginosa Di Poliklinik Kulit Dan Kelamin Blu Rsup Prof. Dr. Rd Kandou Manado Periode JanuariDesember 2012, E-Clinic. 2 (2014).

[20] Armi, Pengaruh Pendidikan Kesehatan Terhadap Tingkat Kepatuhan Pasien Diabetes Melitus Dengan Retinopati Diabetik Dalam Melakukan Pemeriksaan Mata Di Rumah Sakit Aini, (2014).

[21] G. Mongisidi, Hubungan Antara Status Sosio-Ekonomi Dengan Kejadian Diabetes Melitus Tipe 2 Di Poliklinik Interna Blu Rsup Prof. Dr. R. D. Kandou Manado, (N.D.) 8.

[22] A. Ramadona, Pengaruh Konseling Obat Terhadap Kepatuhan Pasien Diabetes Mellitus Tipe 2 Di Poli Klinik Khusus Rumah Sakit Umum Pusat Dr. M. Djamil Padang, M. Djamil Padang. (2011).

[23] S.R. Komariah, U. Dpf, Kolonisasi Candida Dalam Rongga Mulut, Majalah Kedokteran Fkui. 28 (2012) 39-47.

[24] R. Wahyuningsih, S.M. Eljannah, Mulyati, Identifikasi Candida Spp. Dengan Medium Kromogenik, J Indon Med Assoc. 62 (2012) 83-89.

[25] B.R. Shah, J.E. Hux, Quantifying The Risk Of Infectious Diseases For People With Diabetes, Diabetes Care. 26 (2003) 510-513. 